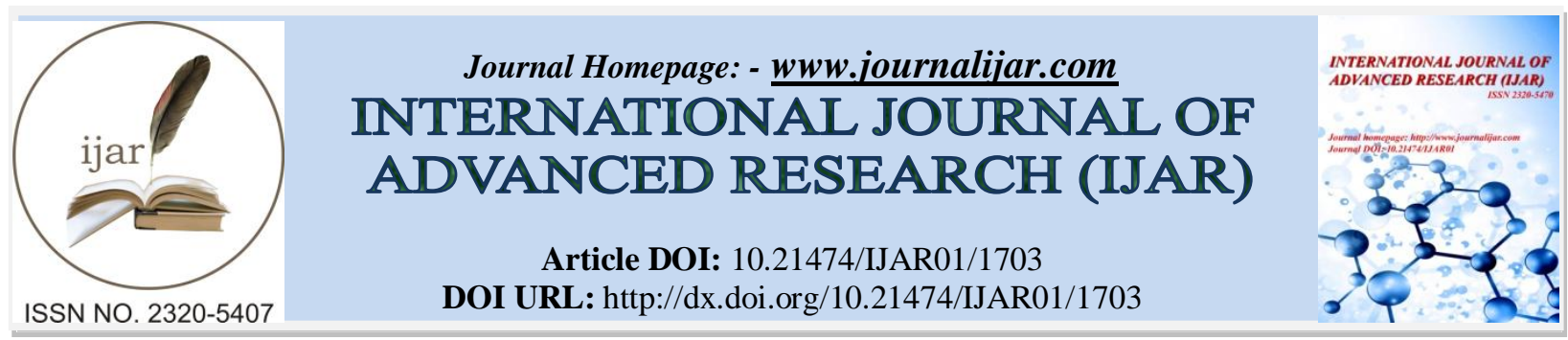

RESEARCH ARTICLE

\title{
THE PRIORITY AND LEGAL BASIS OF THE WATER CONSUMPTION PRINCIPLES IN THE REPUBLIC OF UZBEKISTAN.
}

Jumanov Azamat Oralbaevich.

Senior scientific researcher of "Low" Dean at the Karakalpak State University after the name of Berdakh.

\section{Manuscript Info}

Manuscript History

Received: 16 July 2016

Final Accepted: 22 August 2016

Published: September 2016

Key words:-

water. princip. Law. priority. quality

\section{Abstract}

Join the principles of the use of drinking water, the legal basis of lipids and water illuminated by the analysis of the principles of the rule of law outside its legal framework. A study of the opinion of a number of local and foreign scientists, technical shortcomings law scale attention has been given and the ways to overcome these gaps in research published.

Copy Right, IJAR, 2016,. All rights reserved.

\section{Introduction:-}

It is clear that the legal strengthening of the leading role of the law, its basis, expression of objective laws, institutes of law and field of law, the society's aspirations and needs, which define the whole nature of the system and its general importance are understood under principles of law ${ }^{1}$.

Among all types of institutes of law (there are other points of view on the classification of principles) ${ }^{2}$, it is worth paying attention to the principles of the sub-institutes of law, or, more precisely, to the institute of law for water use that is considered to be more complex. With regard to the issue in question, it is essential to analyze the protocol on the water and health adopted in 1992, in accordance with the International Convention on the use and protection of trans-boundary water tributaries and lakes. (opened for signature in London on 17 June $1999^{3}$ and later continued until June 18, 2000 in the United Nations Headquarters in New York).

Definitely, the right for the provision of the quality water and every party working in this field must follow certain principles:

a. the "polluter pays" principle;

b. supporting the measures on the management of water resources from the lowest administrative level;

c. to administer the water management ensuring the sustainable implementation of social, economic and environmental value of water;

d. to improve efficient use of water by using economic arguments and raise awareness through mass media;

e. to carry out water resources management at all water collection locations in an integrated manner whenever possible, as well as to link closely the management of water resources to the legal measures regulating the

\footnotetext{
${ }^{1}$ Theory of state and law: series of lectures (Edited by N.I. Matuzova and A.V. Malko) - Saratov, SVSh MVD Russia. 1995. p. 122.

${ }^{2}$ Alekseev S.S. Issues of the theory of law. - Sverdlovsk: Sverdlovsk Law Institute, 1972. p. 105.

${ }^{3}$ Brundtlandt G.X. Health is the best investment. // Ekologia i jizn (Ecology and life). - 1999. № 3. p. 63.
} 
quality of other aspects of environment in order to provide close contact between the socio-economic development and protection of natural ecosystems.

* J.T. Xolmuminov indicates some principles connected to the water use law:

* the rational use of water resources;

* protection of water resources;

* close interrelation with all other natural resources;

* use of water resources in accordance with the exact goals indicated in the law;

* water use is directly connected to the environmental policy of the state;

* payment for the use of water;

* timely implementation and fulfillment of all ecological laws along with water legislation;

* timely execution of all international treaties and conventions related to the use of water and others ${ }^{4}$.

* The complexity of the issues linked to water treatment, suggested by S. X. Fayziev, leads to the split of the water law principles into the following system: the state and the general principles of law; special principles concerning water ${ }^{5}$.

* As general principles of state and law are considered the following: the rule of law; social justice; transparency; measures of persuasion and coercion; the unity of rights and obligations of citizens etc.

* The special principles of water protection and its optimal use are observed based on general principles of state and law.

* As the special principles related to water S. X. Fayziev pointed out the following: the preservation of the stability of the natural environment;

* ensuring water rights of the population;

* not charging fee for the common use of water resources;

* payment for the special use of water resources;

* application of state property in relation to water;

* the use of basin water use principle in the management of relationships related to water;

* establishing of incentive measures for the protection and rational use of water;

* obligation of compensation for damage to water and collection of payments;

* obligation of maintaining water cadastre.

* However, the common and special principles stated by S. X. Fayziev are not included in the Law of Republic of Uzbekistan "On water and water use".

* At the same time, the principles stated by J.T.Xolmuminov and S.X.Fayziev are

* fully emphasized in it as to common water use.

Once O.S.Kolbasov V.N.Korzin and A.M.Kavyarin described aforementioned sub-institutional principles as follows: " In order to meet the requirements of the population for drinking water and the household needs by bringing water use in line with modern legal regulations, we have to do with two principles:

first, all natural water resources must be open to all citizens to meet maximally their own needs, and, secondly, all necessary measures shall be taken for the protection of the health of people who are involved in the use of water."

It should be noted that the term "modern" is referred to the parts of the water legislation and the contents of the blocks of regulatory documents of that time.

Moreover, during the independence there were also changes in the terminology in the process of renewing the water law.

In addition to the description of changes included in terminology list, we find it necessary to express some ideas on the content of the principles discussed.

\footnotetext{
${ }^{4}$ Environmental Law. Executive Editor: M.B. Usmanov - T.: Fund for Literature. 2001. - p. 154.

${ }^{5}$ Water law. Tashkent: Tashkent State Institute of Law, 2004. - p. 11.

${ }^{6}$ Kolbasov O.S. Legal bases for drinking water supply for the population of the Russian Federation // Gosudarstvo $i$ pravo (State and law). 1995. № 4. -p. 68.
} 
In particular, according to the necessity of establishing the term "open to all" in the normative document, the requirement that the water facilities must be open to all the population should be taken into consideration during the regulation of the relationships between water users and water consumers, and coordinated in the process of the centralized water supply to the population (unfortunately, this is not stipulated).

However, to meet the needs of the population in drinking water and household needs in decentralized way, to put it simply, when they use rivers, lakes and springs, it is obviously not necessary to mention it specially.

In addition, the role of water bodies depends on the complexity of the local territorial structure and other natural conditions.

Therefore, such cases should be taken into consideration during the discussion of the problems related to the improvement of the current legislation, or at least, from the point of implementing the goals on complex use of water bodies.

For example, the purpose of the use of water is to meet the needs of the population for drinking water and household needs in general, as well as implementing this according to the regulations on general and special water use.

Along with that according to the decree of the Council of Ministers of the Republic of Uzbekistan (Article 27 of the Law "On Water and Water Use"),

the water bodies considered republican property are used specifically for the purpose of national defense, energy system, public transport, as well as for state and municipal needs.

This means that, the special use of water is the kind of use with a number of limitations and it cannot be open to all.

That is why in the decisions of the relevant government agencies about the special use of water bodies, special attention should be paid to the incessant provision of drinking water to the population and their household needs. In addition, to meet the population's needs for drinking water and household needs the water bodies having certain quality indicators ${ }^{7}$ should be used.

This, in turn, influences directly the contents of the second principle of «ensuring human health with all measures related to the use of water ".

In our opinion, here, we should mention that acting according to this principle should be guaranteed. According to experts, by 2015 more than half the population of the planet earth, had difficulties associated with drinking water.

This led to the need of official registration of the modern legal bases of the changes occurred, that is, to the adoption of the Constitution of the Republic of Uzbekistan, renovation of the existing legislation (including the legislation on water use and consumption).

According to Yu.V.Novikov, as fundamental principles of drinking water supply, should be recognized the following:

a. first and foremost the state must guarantee the provision of drinking water to the citizens so that they can ensure their own vital needs and protect their health;

b. to regulate the issues of drinking water supply, the authorities responsible for the drinking water supply must report to the

c. State control authority, the executive authority and local authorities, as well as to the state control bodies, the civil defense and emergency situations bodies;

d. to ensure the safety, reliability and management of drinking water in accordance with the norms and unified standard of drinking water supply system used in the territory, paying attention to its technological features and the ways of selection of the water supply sources, and taking into account the prioritized trends in using underground sources of drinking water.

7 . Snakin V. Ecology and nature protection: Reference Dictionary (Edited by A.L. Yanshina) - M .: Academia, 2000. - p. 56. 
e. drinking water supply must be registered and planned;

f. the raw materials for drinking water supply, as well as production and delivery of chemicals and equipment for water treatment must be supported by the state;

g. drinking water supply system should be included in the ranks of the objects of vital importance ${ }^{8}$.

Proceeding from the above-mentioned principles, instead of raising to the level of principle the narrow household activity such as "producing raw materials, equipment and chemicals used for water treatment and disinfection" it can be recognized as much larger field of activity - as part of water protection or with some changes for another definite goal that is using the water bodies for excess and drainage water'.

In addition, here, V.P.Orlov's point of view is also worth mentioning. In his opinion, "the problem of prevention of pollution of drinking water can be solved by complex approach to the use of potential resources of great river basins, and it is based on the following principles:

The effective use of renewable natural resources supply;

The use of secondary resources and establishing effective decontamination and disposal of waste;

Environmentally safe placement of the productive forces and production, development of energy, transportation, utilities, and agriculture without harming the nature $" 10$.

The principles noted by V.P.Orlov have general nature for the water body used in agricultural activity, manufacturing, transportation, municipal and household water supply areas. As for the principle of "the use of renewable natural resources supply," a more accurate analysis is required here.

In theory, the question whether the content of the above-mentioned principles correspond to the general principles of the institution on water use, or, if there is any conflict of interests between them, may naturally arise.

K. A. Shaybekov ${ }^{11}$, believes that the principle on treating natural objects, including water resources, as the stateowned property is the most important.

The principle on the exploitation of water facilities according to a certain regulation pertaining to the legal institution on the water use is still actual. Contrary to some ideas requiring that during the transition to the market economy much importance should not be attached to the planning of the national economy, there is necessity to keep the priority of planning in the water management. As an example of this, we can name the state management of the use of water bodies and their protection.

In particular, in the state program for the period 2000-2010 to provide drinking water to the rural population, in the project on the development of rural water supply in western Uzbekistan (Karakalpakstan and Khorezm region), in the program on the improving of the local water supply in Bukhara, Gulistan, Jizzakh, Nukus, Karshi, Samarkand, Khiva and other regional centers, the state duty on exploitation and protection of water bodies is defined.

Just as the most important link in the principles of the use of water facilities for drinking and household water supply is stated in the above-mentioned literature, the content of the principle on complex use of water is also reflected in them.

\footnotetext{
${ }^{8}$ Novikov Yu.V. Ecology, environment and human. Textbook. - M .: Fair, 1998. - p. 84.

${ }^{9}$ The principles of the use of water bodies for drinking and household water supply and their implementation in the legislation of Russia // Pravovedenie (Jurisprudence). 2001. № 6. p. 99

${ }^{10}$ Orlov V.L. State and problems of conservation of natural resources in the basins of the great rivers of Russia: International scientific industrial forum "Great rivers-99": General reports on problems of environmental rehabilitation of the great rivers of the world - Nizhny Novgorod: VAO "Nijnegorodskaya yarmarka" ("Nizhny Novgorod Fair"), 1999. - V. 1. p.10

${ }^{11}$ Shaybekov K.A. Principles of Water Legislation // Almaty Institute of Law. V. 1. -Almaty, Yurizdat, 1955. -p.151
} 
We believe that the attempts to include the essence of this principle in principles of the institute on the ownership of water bodies are groundless.

Just to illustrate this stance, we can quote here the following ideas stated by I. A. Romshin: "Government should be entrusted the right to give water objects to the individuals only if they ensure the right for all and every citizen to use these objects. For example, if the water object is given to certain legal entity for industrial water supply or for recreation, their further use for such goals, must not be a barrier to citizens' and legal entities' use of water "12.

Determining the content of the principles on the use of water for drinking and household needs supply allows specialists to start analyzing the normative documents coordinating the relations in the natural use of water. Moreover, along with this it allows to find out how the ideas described in the aforementioned principles are being implemented in practice.

First of all, we shall refer to Article 25 of the Law "On Water and Water Use", which includes regulating the issue under discussion. According to it, water bodies are primarily used to meet the population's needs for drinking water and household needs.

This implies that practical fulfillment of this goal is legally supported, and use of water bodies is prioritized over other goals.

It is necessary to understand the importance of social or economic goal in the use of water bodies as a criterion to make a reasonable decision on the issue. Naturally, the lawmakers believe that meeting the demands of the population for drinking water and household needs to be the main task. The topic was developed by our scientists, and now is reflected in national legislation. For example, the Law of the Republic of Uzbekistan "On the sanitaryepidemiological wellbeing of the population" from August 26, 2015 says that "Legal entities, carrying out activities in the field of drinking and service water supply, are required to ensure that supplied water meets the sanitary rules, regulations and norms of hygiene, as well as state standards ". (The first part of Article 26).

In conclusion, we have the right to raise the issue of the assurance that this priority is maintained and thereby ensure its firm focus, and that the needs of interested parties for sufficient quantities of quality drinking water are met.

Human safety criteria for the water bodies are regulated by the sanitary rules.

\footnotetext{
${ }^{12}$ Romshin I.A. Issues of the improvement of the legal regulation of property relations concerning water bodies: Environmental law and agrarian-legal problems of the modern period: Inter institute collection of scientific works. Ekaterinburg: UrPOA Publishing house, 2000. - p. 213.
} 